\title{
Mössbauer Studies of Volhynian Basalts
}

\author{
N. Bakun-Czubarow ${ }^{a}$, J. Milczarski ${ }^{b}$, J. GalaszKa-Friedman $^{b}$, K. Szlachta $^{b}$ \\ AND S. FORDER ${ }^{c}$ \\ ${ }^{a}$ Institute of Geological Sciences of the Polish Academy of Sciences, Twarda 51/55, 00-818 Warszawa, Poland \\ ${ }^{b}$ Faculty of Physics, Warsaw University of Technology, Warszawa, Poland \\ ${ }^{c}$ Sheffield Hallam University, Sheffield, S1 1WB UK
}

\begin{abstract}
The Volhynian basalts studied belong to the effusive-tuffogenic Volhynian Series (Sławatycze Series in Poland), being the large Ediacaran continental igneous province, that covers an area of $200000 \mathrm{~km}^{2}$ in the western margin of East European Craton. The series is underlain by the Cryogenian terrigenous Polesie Series with doleritic sills and dikes. The Volhynian Series consists of the rock beds belonging to the three volcanic cycles with different ratios of flood basalts to pyroclastics. The aim of the study was recognition of primary and secondary Fe-bearing minerals, particularly Fe- and Fe-Ti oxides as well as determination of iron oxidation state, that is an important tool in the search for native copper deposits in these rocks. For Mössbauer studies the following rock samples were chosen: the Polesie Series dolerites, the Volhynian Series basalts from the Ukrainian quarries and drill-holes, e.g. from the Volodymir Volhynskaya drilling hole; the Sławatycze Series basalts from Kaplonosy drill-hole in Poland. In the Kaplonosy basalts the content of magnetite decreases with depth, which may be caused by magma differentiation due to fractional crystallization, when $\mathrm{Mg}$ content decreases as $\mathrm{Ti}$ and $\mathrm{Fe}$ - increases in basic magma. In the Kaplonosy basalts the $\mathrm{Fe}^{2+} / \mathrm{Fe}^{3+}$ ratio increases with depth, which points to the increase of iron oxidation with the progress of basaltic magma differentiation.
\end{abstract}

PACS: $91.25 . \mathrm{F}-$

\section{Introduction}

Ediacaran continental flood basalts of the Volhynian Igneous Province (VIP), in the western margin of East European Craton cover an area of about $200000 \mathrm{~km}^{2}$ (Fig. 1) and reach the overall thickness of $600 \mathrm{~m}$, thus they form a large igneous province - LIP [1]. In the VIP, there can be distinguished the two effusive-tuffogenic series: Volhynian Series (VS) in Ukraine and Sławatycze Series (SS) in eastern Poland, underlain by terrigenous deposits of the Polesie Series (PS) with the Cryogenian doleritic sills and dikes. Within VS and SS the rocks of three volcanic cycles, with different ratios of flood basalts to pyroclastics, can be distinguished. In the SS, the following rocks - from bottom to the top of the series - were found: picrites of the I volcanic cycle; medium Ti (MTi) tholeiitic basalts of the II cycle and low Ti (LTi) quartz tholeiites of the III cycle. In the VS, the three volcanic cycles can be also distinguished: I cycle is represented by olivine tholeiites, II cycle — by quartz tholeiites, while the upper quartz tholeiites together with basaltic andesites represent the III volcanic cycle $[2,3]$. At the present state of knowledge the most probable seems to be the hypothesis that primary magma for the VIP continental flood basalts (CFBs) has been originated in Ediacaran, within the head of asthenospheric plume, beneath triple junction between Fennoscandia, Sarmatia and an unknown plate (most likely Amazonia).

The aim of the Mössbauer studies of the VIP flood basalts was to obtain new data on iron oxidation state in basaltic rocks as well as on distribution of iron between co-existing Fe-bearing mineral phases. These data are necessary for further progress in both basic and applied research on origin and evolution of basaltic magma in large igneous provinces. The applied research is chiefly oriented on the prospecting for the native copper deposits in the VIP flood basalts, as $\mathrm{Cu}$ metallogenic processes require relatively low value of redox potential in the basaltic environment, that corresponds to the low value of the iron oxidation state.

\section{Material and methods}

The results of petrological and geochemical comparative studies of SS and VS as well as the lack of picritic rocks in VS point that the SS MTi basalts of II cycle correspond to the I cycle olivine tholeiites of VS, while the III cycle LTi tholeiites of SS correspond to the II cycle quartz tholeites of VS. The equivalents of III cycle quartz tholeiites and basaltic andesites of VS have not been found yet in SS.

For the Mössbauer studies the following VIP rock samples listed in Table (cf. Fig. 1) were chosen:

I) the four Cryogean dolerites from PS drill-holes: 1. in Berestechko, 2. in Ovadno, 3. drilling No. 40, 4. in Radovichi-Ovadno;

II) seven samples of Ediacaran continental flood basalts of VS: 5 . from Bazaltovoye quarry (II cycle), 6. from drilling No. 5815 on the ŁukówRatno horst (I volcanic cycle), $7 \div 11$. from drill-hole Volodymir Volhynskaya (I and II volcanic cycles); 


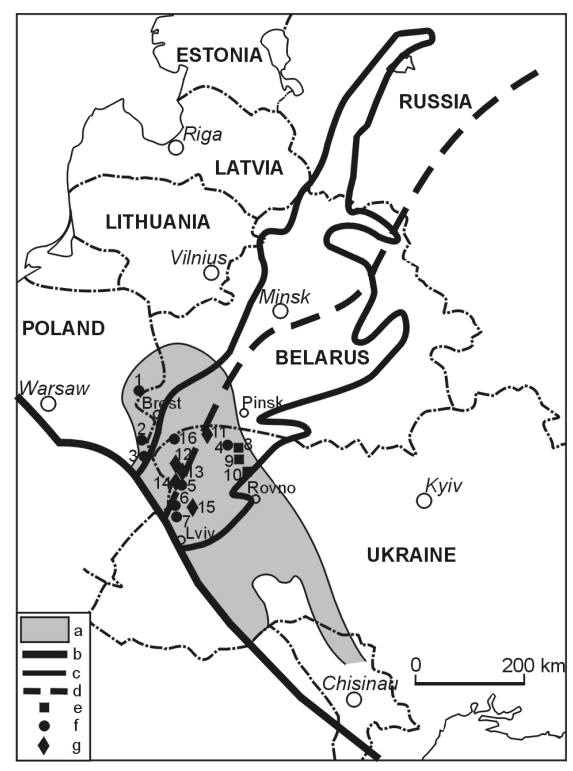

Fig. 1. Sketch map of the large Neoproterozoic Volhynian Igneous Province. (a) Volhynian Igneous Province, (b) Trans-European Suture Zone, (c) boundary of Orsha-Volhynia aulacogen, (d) Fennoscandia-Sarmatia Suture, (e) quarry in Ediacaran flood basalts, (f) drilling in Ediacaran flood basalt, (g) drilling in Cryogean dolerites. Sample localities: 1. Mielnik, 2. Kaplonosy, 3. Busówno, 4. drilling No. 5879, 5 and 14. Volodymir Volhynskaya, 6. Litovezhskaya, 7 . Noviy Vitkov, 8. Politsy, 9. Ivantse, 10. Bazaltovoye (JDIV), 11. drilling No. 40, 12. Ovadno, 13. Radovichi-Ovadno, 15. Berestechko, 16. drilling No. 5815.

III) ten samples representing three volcanic cycles of Ediacaran continental flood basalts of SS, from drilling in Kaplonosy: $12 \div 15$ - III volcanic cycle, $16 \div 18$ - II cycle as well as $19 \div 21$ - picrites of the I volcanic cycle.

Prior to Mössbauer measurements, the hand-sized basalt samples were covered with a cloth and crushed to smaller pieces with a rock hammer. The freshest pieces of the crushed rocks were carefully hand-picked and powdered in an agate mortar under alcohol in order to avoid oxidation of iron. Mössbauer measurements were performed then on the dry powdered samples at room temperature using a constant acceleration spectrometer. A ${ }^{57} \mathrm{Co}$ source in a rhodium matrix was used. The activity of the source was $30 \mathrm{mCi}$. The spectrometer was calibrated with the use of an $\alpha$-Fe foil. Mössbauer spectra were analyzed by means of the Recoil program. As entrance parameters in the procedure of fitting, values of IS, QS and H, obtained in others laboratories, were applied [4]. The following order of fitting of subspectra of the basalt rock-forming Fe-bearing minerals to the measured Mössbauer spectra was applied: magnetite, pyroxenes, titanomagnetite, olivine, chlorite, hematite. The ratio of $\mathrm{Fe}^{2+} / \mathrm{Fe}^{3+}$ was determined from the overall spectral area of ferrous and ferric subspectra.
TABLE

Results: percentage of total iron contained in particular mineral phases of the basaltic rock.

\begin{tabular}{|c|c|c|c|c|c|c|c|c|}
\hline $\mathbf{S}$ & p & i & ch & $\mathbf{m}$ & $\mathbf{t}$ & $\mathbf{h}$ & o & $2 / 3$ \\
\hline 1 & 42 & 28 & 13 & 15 & 2 & 2 & 0 & 1,51 \\
\hline 2 & 30 & 34 & 0 & 11 & 9 & 0 & 16 & 3,09 \\
\hline 3 & 33 & 38 & 0 & 10 & 6 & 12 & 0 & 1,72 \\
\hline 4 & 35 & 9 & 42 & 10 & 5 & 0 & 0 & 0,81 \\
\hline 5 & 40 & 0 & 34 & 11 & 6 & 0 & 9 & 2,74 \\
\hline 6 & 39 & 17 & 0 & 14 & 12 & 0 & 18 & 3,25 \\
\hline 7 & 28 & 28 & 16 & 7 & 7 & 18 & 0 & 1,03 \\
\hline 8 & 30 & 4 & 22 & 33 & 3 & 0 & 0 & 2,16 \\
\hline 9 & 15 & 20 & 0 & 30 & 3 & 31 & 0 & 0,33 \\
\hline 10 & 34 & 28 & 0 & 17 & 1 & 6 & 15 & 1,96 \\
\hline 11 & 45 & 0 & 12 & 23 & 0 & 4 & 0 & 2,72 \\
\hline 12 & 29 & 9 & 0 & 46 & 1 & 15 & 0 & 0.75 \\
\hline 13 & 15 & 0 & 19 & 41 & 11 & 14 & 0 & 0,53 \\
\hline 14 & 42 & 2 & 0 & 41 & 1 & 12 & 0 & 0,62 \\
\hline 15 & 8 & 16 & 21 & 38 & 11 & 8 & 0 & 1,39 \\
\hline 16 & 69 & 0 & 0 & 24 & 5 & 2 & 0 & 1,19 \\
\hline 17 & 58 & 2 & 0 & 21 & 18 & 2 & 0 & 1,98 \\
\hline 18 & 30 & 0 & 44 & 18 & 5 & 3 & 0 & 3,18 \\
\hline 19 & 81 & 0 & 0 & 16 & 0 & 3 & 0 & 1,26 \\
\hline 20 & 60 & 0 & 20 & 12 & 5 & 0 & 0 & 2,3 \\
\hline 21 & 36 & 0 & 54 & 8 & 2 & 0 & 0 & 2,56 \\
\hline \multicolumn{9}{|c|}{$\begin{array}{l}s-\text { number of the sample, } p-\text { pyroxene, } \\
i-\text { ilmenite, ch - chlorite, m- magnetite, } \\
t-\text { titanomagnetite, } h-\text { hematite, o - } \\
\text { olivine, } 2 / 3-\text { ratio of } \mathrm{Fe}^{2+} \text { to } \mathrm{Fe}^{3+}\end{array}$} \\
\hline
\end{tabular}

\section{Results and discussion}

In the course of preliminary mineralogical investigations of the chosen basalt samples, performed under an optical microscope in the polarized transmitted light as well as by means of electron microprobe analyses (EMPA), apart from feldspars, quartz and volcanic glass, the following iron-bearing rock-forming minerals were identified: pyroxene, olivine, chlorite, magnetite, titanomagnetite, ilmenite and hematite. From among the last group of minerals chlorite and hematite belong to the secondary minerals, that crystallized during hydrothermal alteration of basalts.

In the course of Mössbauer studies, in all 21 investigated samples paramagnetic and magnetic mineral phases were observed. Typical Mössbauer spectra of the two samples of the VIP basalts are shown in Fig. 2 and Fig. 3. They represent picrites of the I volcanic cycle (with high $\mathrm{Fe}^{2+} / \mathrm{Fe}^{3+}$ ionic ratio) as well as tholeiitic basalts (with low $\mathrm{Fe}^{2+} / \mathrm{Fe}^{3+}$ ionic ratio) of the III volcanic cycle of SS. For Mössbauer identification of different Fe-bearing mineral phases information obtained from 
preliminary mineralogical investigations of the basalts was used. In Table the percentage of iron ions present in different minerals in all 21 samples and the value of $\mathrm{Fe}^{2+} / \mathrm{Fe}^{3+}$ ratio are shown. In the investigated samples the following primary — pyroxene, olivine, ilmenite, magnetite, titanomagnetite, as well as secondary mineral phases: chlorite and hematite — were identified.

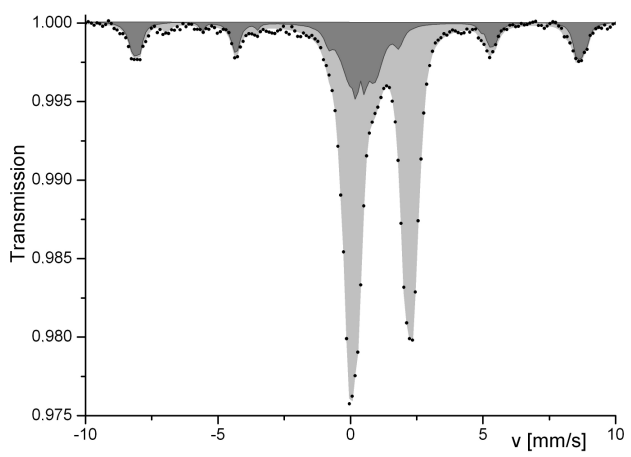

Fig. 2. Mössbauer spectrum of the picrite sample No. K1751 of the SS I volcanic cycle from the Kaplonosy drill-hole (No. 20 in Table). Dark gray shows contribution of ferric iron to total spectrum.

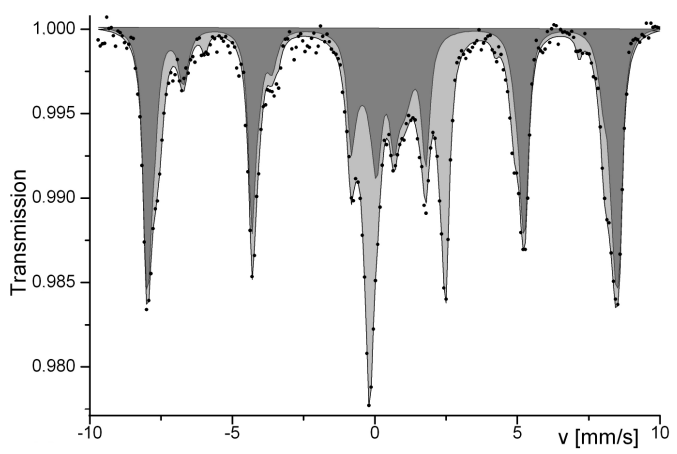

Fig. 3. Mössbauer spectrum of the basalt sample No. K1485 of the SS III volcanic cycle from the Kaplonosy drill-hole (No. 13 in Table). Dark gray shows contribution of ferric iron to total spectrum.

In Fig. 4 the interrelationship between $\mathrm{Fe}^{2+} / \mathrm{Fe}^{3+}$ ionic ratio and the depth of the basaltic samples in the Kaplonosy drill-hole profile is shown. The simple positive correlation between the two above mentioned parameters can be observed. This correlation confirms the hypothesis concerning the increase of iron oxidation state with the progress of magma differentiation due to fractional crystallization within the three volcanic cycles of SS, registered in the Kaplonosy profile. Moreover, the highest value of $\mathrm{Fe}^{2+} / \mathrm{Fe}^{3+}=3.18$, jumping off the regression line, belongs to the Kaplonosy basalt sample mineralized with native copper. Thus, Mössbauer determination of iron oxidation state in basaltic rocks became a perspective tool in prospecting for native copper deposits.

In the Kaplonosy profile, Table, samples $12 \div 21$, the percentage of total iron contained in magnetite increases from bottom (cycle I) to the top (cycle III). On the average, magnetite of cycle I basalts contains 12 ionic $\%$ of total $\mathrm{Fe}$, in cycle II - 21 ionic $\%$ of $\mathrm{Fe}_{t o t}$ is contained in magnetite, while in basalts of cycle III magnetite contains over 41 ionic \% of $\mathrm{Fe}_{t o t}$. This observation is consistent with the trend of basaltic magma differentiation due to fractional crystallization, when with decreasing depth $\mathrm{Mg}$ content decreases as $\mathrm{Fe}$ and $\mathrm{Ti}$ increases. Thus, in basic research of large igneous provinces, Mössbauer investigation of the percentage of total iron contained in magnetite can become an effective tool for correlation of volcanic cycles in dismembered profiles of LIPs.

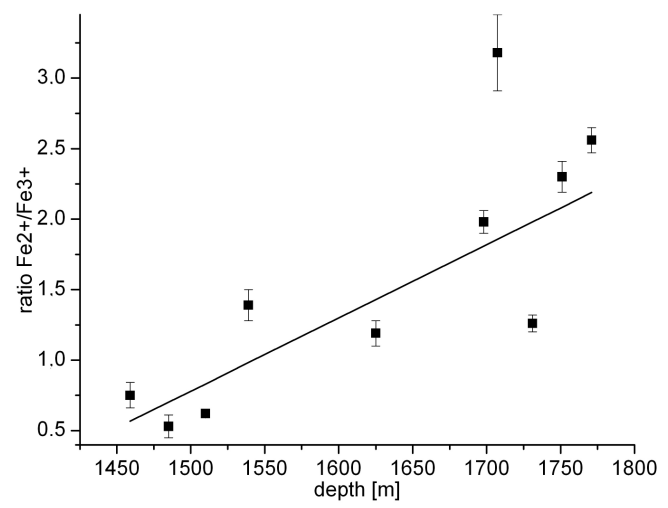

Fig. 4. The $\mathrm{Fe}^{2+} / \mathrm{Fe}^{3+}$ ionic ratio in Kaplonosy basalts in a function of depth.

\section{Acknowledgement}

The presented studies were partly supported by the grant of Polish Ministry of Science and Higher Education, project No. 2 P04D 03829.

\section{References}

[1] S.E. Bryan, R.E. Ernst, Earth Sci. Rev. 86, 175 (2008).

[2] A. Białowolska, N. Bakun-Czubarow, Yu. Fedoryshyn, Geol. Q. 46, 37 (2002).

[3] N. Bakun-Czubarow, A. Białowolska, Yu. Fedoryshyn, Acta Geol. Pol. 52, 481 (2002).

[4] Mössbauer Mineral Handbook, Eds. J.G. Stevens, A.M. Khasanov, J.W. Miller, H. Pollak, Z. Li, Mössbauer Effect Data Center, Asheville, North Carolina 1998, p. 527. 